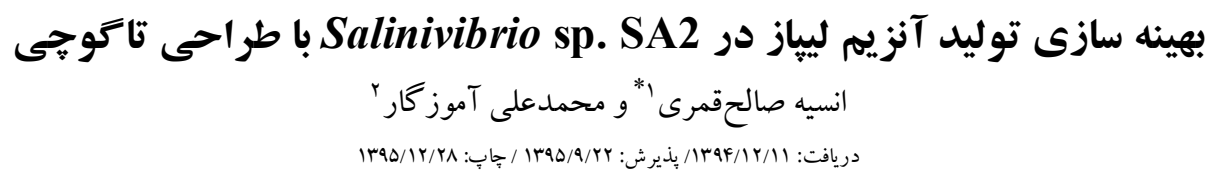

$$
\begin{aligned}
& \text { اكروه علوم سلولى و مولكولى، دانشكاه خوارزمى، تهران، ايران }
\end{aligned}
$$

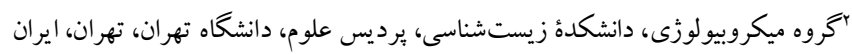

$$
\begin{aligned}
& \text { esaleh@khu.ac.ir :مسئول مكاتبات }
\end{aligned}
$$

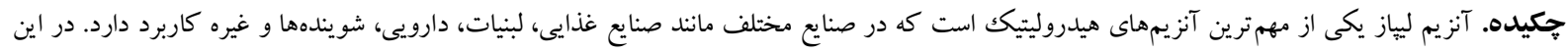

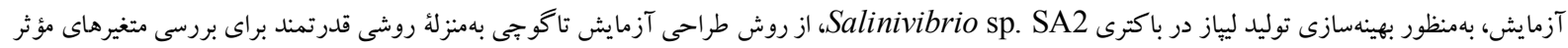

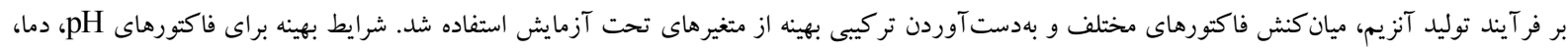

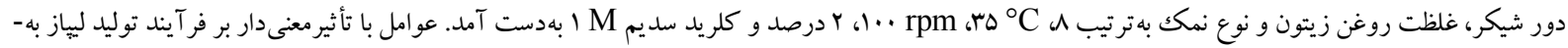

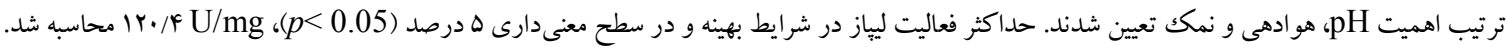

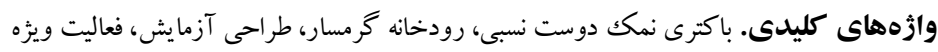

\title{
Optimization of lipase production in Salinivibrio sp. SA2 by Taguchi design
}

Ensieh Salehghamari ${ }^{1 *} \&$ Mohammad Ali Amoozegar ${ }^{2}$

Received 01.03.2016/ Accepted 12.12.2016 /Published 18.03.2017

${ }^{1}$ Department of Cell and Molecular Biology, Faculty of Biological Science, University of Kharazmi, Tehran, Iran ${ }^{2}$ Department of Microbiology, School of Biology, University College of Science, University of Tehran, Tehran, Iran Correspondent author: esaleh@khu.ac.ir

Abstract. Lipase is one of the most important hydrolytic enzymes widely used in various commercial activities such as food, dairy, pharmaceutical and detergent inducteries. In this experiment, Taguchi method was attempted as a powerful method to optimize the factors affecting enzyme production and to investigate the interactions among these factors and their optimum combination in Salinivibrio sp. SA2. The optimum conditions for $\mathrm{pH}$, temperature, shaker's rpm, olive oil concentration and salt type turned out to be $8,35{ }^{\circ} \mathrm{C}, 100 \mathrm{rpm}, 2 \%$ and sodium chloride $1 \mathrm{M}$, respectively. Significant factors influencing on the lipase production proved to be $\mathrm{pH}$, agitation and Salt type. The maximum lipase activity in optimum condition and at the $5 \%$ significance level $(p<0.05)$ was $120.4 \mathrm{U} / \mathrm{mg}$.

Keywords. experimental design, Garmsar river, moderate halophilic bacteria, specific activity

بر اى صنايع سخت كه در آنها غلظتهاى بالاى نمكى به غيرفعال

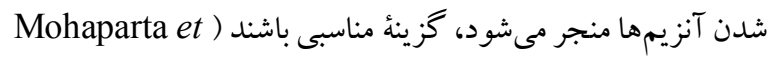
(al., 1998; Gutiérrez-Arnillas et al., 2016 نمككدوست نسبى گروهى از باكترىهاى نمككدوست هستند كه در غلظت (w/v) ه-1ه درصد كلريد سديم قادر به رشدند (Babavalian et al., 2013). نمككدوستهاى نسبى شامل

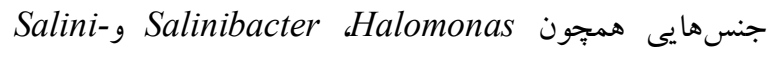
هibrio

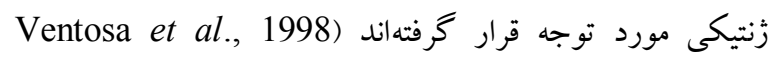
Kumar et al., 2012;
مقدمه آنزيم ليياز باكتريايى يكى از مهم ترين آنزيمهاى هيدروليتيكك است و بهطور كستردهاى از نظر آنزيمشناسى بررسى شده است.

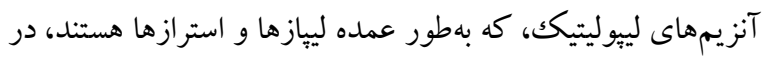
صنايع غذايى، شويندها، صنايع لبنى، جرمسازى، داروسازى و شيميايى بهطور وسيعى كاربرد دارند ( (Jaerger et al., 1999 باكترىها هستند. در اين ميان جداسازى باكترىهاى نمككدوست نسبى توليد كننده آنزيمهاى هيدروليتيك به يافتن آنزيمهاى مقاوم به غلظتهاى بالاى نمكك منجر مىشود. اين آنزيمها مىتواند 
تركيبات محيط توليد نيمهصنعتى ليّاز شامل (gr/l): ب يجتون، ه/1/

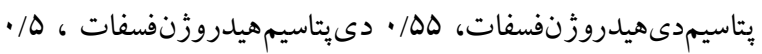

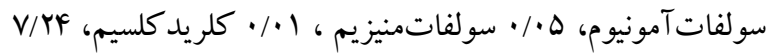
كلريدسديم، ه/ • عصارهُ مخمر و روغن زيتون (تهيه شده از شركت سيخما) است كه با ا درصد تلقيح از محيط بيش كشت به -

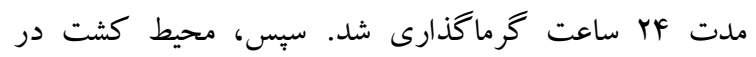

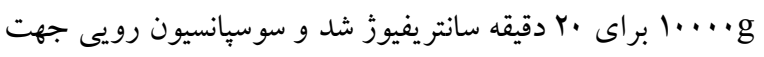
سنجش ليپاز تحت بررسى قرار گرفت (Dalmau et al., 2000).

\section{بهينهازى آنزيم و طراحى آزمايش} براى بهينهسازى آنزيم ليِاز ينج فاكتور در دو سطح شامل دما، ، دور شيكر، غلظتهاى روغن زيتون و دو نمك كلريد سديم و كلريد يتاسيم تحت بررسى قرار گرفتند (جدول (). اين فاكتور ها و سطوح آنها، بر اساس كار هاى قبلى انجام شده بر روى اين آنزيم انتخاب شدند (Amoozegar et al., 2008). براى بهينه سازى فاكتورهاى انتخابشده بهروش تاكوجى از آرائ متعامد L16 استفاده شد (جدول Y). ميان كنش هر فاكتور با جهار فاكتور ديخر نيز بررسى شد. براى تحليل و سنجش دقيقتر نتايج آزمايش هاى طراحىشده با روش تاگوجى از يك تابع پاسخ تبديل يافته استفاده مىشود كه به صورت نسبت علامت هر اثر (S) به اثرات ناشى از خطا (N) تعريف مىشود. مزيت استفاده از اين پِاسخ جديد در تحليلهاى آمارى، نسبت به ياسخ اوليه، مقايسه بزركى آثار ناشى از هر عامل اصلى با آثار ناشى از عوامل خطا در اندازهـگيرى است. آزمايشها سه مرتبه تكرار و ميانگين مقادير آنها به صورت نتايج نهايى به كمك نرمافزار Qualitek-4 تجزيه و تحليل آمارى شد و درنهايت، شرايط بهينهُ واكنش تخمين زده شد.

\section{سنجش فعاليت آنزيم ليياز}

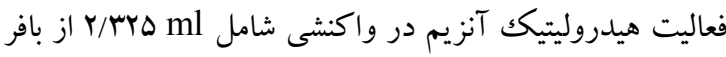

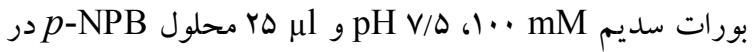

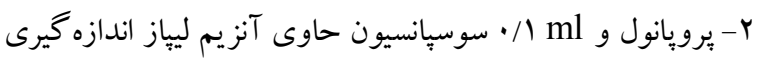
شد. غلظت نهايى مواد بهصورت ذيل بود: بيشماده

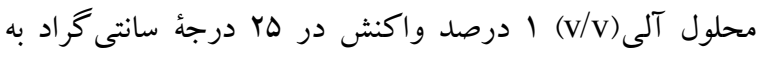
مدت •4 ثانيه انجام گرفت. تغييرات جذب در N1. nm اندازه-

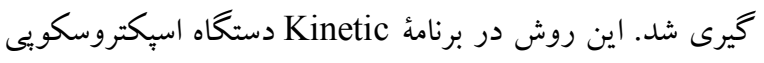
انجام شد و با داشتن ضريب جذب مولى (ع) يارانيتروفنول و مسير عبور نور در كووت، غلظت يارا- (IN1/Al.9 cm²/mol)
غلظتهاى نمكى بالا توسط باكترىهاى نمكدوست، مطالعات كاربردى كمترى در حوزه زيست فناورى دربارهٔ آنها به انجام Esteban-Torres et al., 2015; Schreck \& ) رسيده است Grunden, 2014 . براى مثال، باكترىهاى نمككدوست نسبى رشد سريع دارند، به غذايى ساده نياز دارند و منابع كربنى مختلفى را مى تواند استفاده كنند، ضمن اينكه كشت آنها بهراحتى آلوده نمىشود (Kamekura \& Kushner; 1984)، ولى با وجود اين آنزيمهاى كمى از آنها شناسايى و بهينهسازى شده است Ventosa \& Nietoj, 1995; Esteban-Torres et al., ) 2015). توليد ليياز توسط باكترى تحت تأثيرتعدادى فاكتور مانند Kim et al., ( منبع كربن، pH دما، دور شيكر و نوع نمكك است 1996). در اين مقاله توليد آنزيم ليياز در Sp2 SA2 به كمك روش تاكوجى بهينهسازى شده است. اين Salinivibrio مطالعه آمارى اطلاعات مناسبى را در زمينهُ ميان كنش بين فاكتورها و نيز كاهش تعداد آزمايش براى بهدست آوردن شر ايط بهينهُ توليد آنزيم ليخاز فر اهم ساخته است.

\section{مواد و روشها}

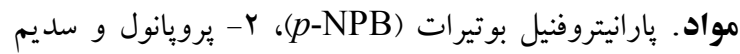
بورات از شركت سيخما و روغن زيتون، نمككها و محيطهاى كشت از شر كت مركى تهيه شدند.

دستغاهها. ميكروسكوب نورى مدل Kalrlzeis، اسبكتروفتومتر Shimadzo مدل UV- 160A و سانتريفوز labfuge400 مدل Heraus باكترى. Salinivibrio Sp. SA2 نوعى باكترى نمككدوست نسبى است كه به كوشش Amoozegar و همكاران (2008) از رودخانة گرمسار جداسازى شده است. توليد آزيم ليياز آمادهسازى تلقيح

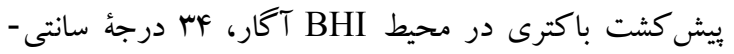
كراد، pH V/Y-V/F و دور شيكر لrpm ادرصد از محلول ه مكك فارلند كشت داده شد. محيط كشت توليد با كشت حدودا 9 ساعته (19.=1A600) از محيط بيش كشت به اندازه (V/V) ادرصد تلقيح شد. محيط كشت توليد ليڤياز 
جدول ا- فاكتورها و سطوح بررسى شدة آنها در بهينهازى توليد آنزيم ليياز در Salinivibrio sp. SA2 به روش تاكو تحى.

Table 1. Factors and their levels of application on the optimization of the lipase production by Salinivibrio sp. SA2 using Taguchi method.

\begin{tabular}{|c|c|c|c|}
\hline سطح r & سطح ' & 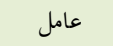 & \\
\hline$\wedge$ & v & $\mathrm{pH}$ & A \\
\hline$\% r(w / v)$ & $\% 1(\mathrm{w} / \mathrm{v})$ & روغن زيتون & B \\
\hline هادرجهُ سانتى گراد & هזدرجهُ سانتى گراد & دما & $\mathrm{C}$ \\
\hline $10 \cdot \mathrm{rpm}$ & $1 \cdots \mathrm{rpm}$ & دور شيكر & D \\
\hline $\mathrm{NaCl} \backslash \mathrm{M}$ & $\mathrm{KCl} \cdot / \mathrm{M}$ & نمكك & E \\
\hline
\end{tabular}

فعاليت ويزٔه آنزيم، اثر اصلى هر فاكتور بدون درنظر گرفتن ميان-

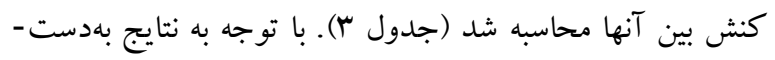

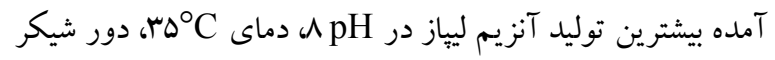

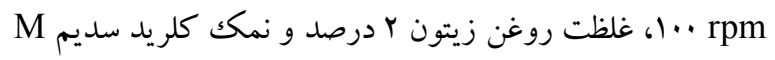

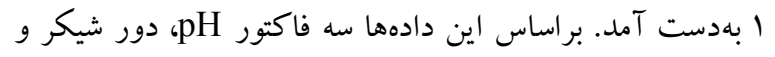
نوع نمك تأثيربيشترى در مقايسه با دو فاكتور ديخر در توليد آنزيم

داشتند.

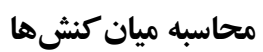
برخى تأثيرات بر توليد آنزيم ناشى از خود فاكتورها بهطور

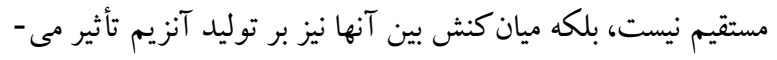

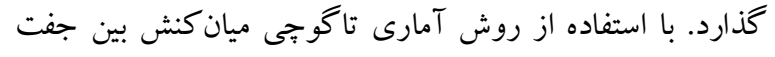
متغيرهاى واكنش بررسى و نتايج در جدول \& آورده شده است. با بال

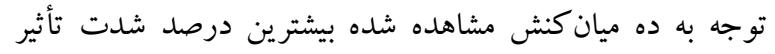
متقابل يعنى / V• بين دما و pH و كمترين درصد ميان كنش معادل

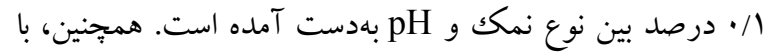
توجه به جدول fا، بين فاكتورهاى دما و دور شيكر و غلظت روغن و نمكك نيز ميان كنش درخور توجهى وجود دارد.

تحليل واريانس (ANOVA)

در جدول ه، تحليل واريانس نتايج حاصل از توليد آنزيم ليياز با هو درصد اطمينان در قالب جدول ANOVA ارائه شده است. سبس، واريانس خطا با استفاده از روش آمارى Pooling انجام إندام كرفت و درجهُ معنىدار بودن دادههاى بهدست آمده محاسبه شد.

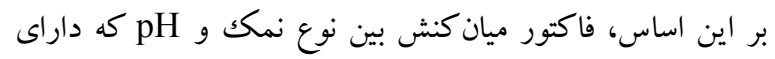

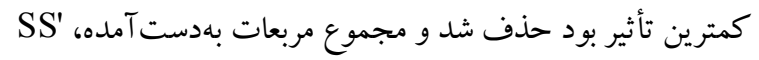

نيتروفنول توليدشده بهدست آمد. يكك واحد آنزيمى برابر است با

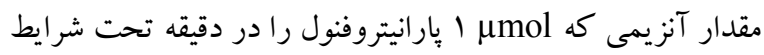

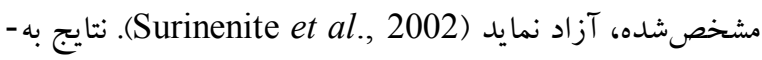
دست آمده براى سنجش فعاليت آنزيم ليياز با واحد فعاليت آنزيم به ازاء كل بروتئين اندازهيرى شده (U/mg) بيان شده است

\section{نتايج}

در اين بُزوهش از روش آمارى تاكوجى بهمنزله يكى از

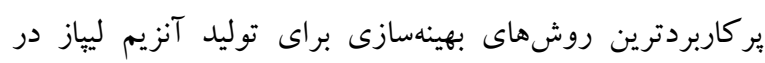
باكترى نمككدوست نسبى Salinivibrio sp. SA2 استفاده شد.

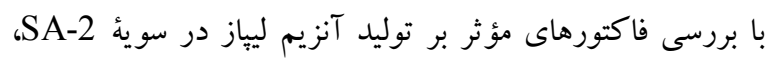

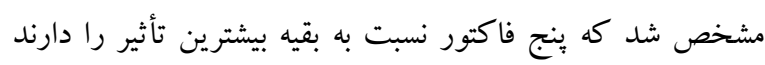

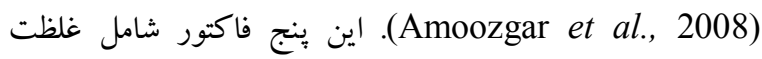
روغن زيتون، غلظت و نوع نمكك (كلريدسديم و كلريديتاسيم)، s.pH

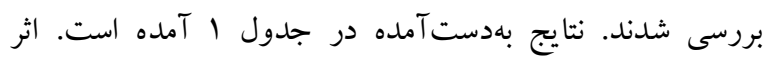
متقابل جفت متغيرهاى مختلف بر ميزان توليد آنزيم ليپياز، تعيين

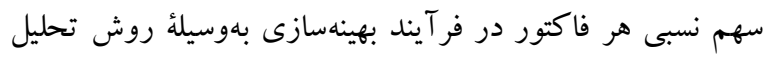

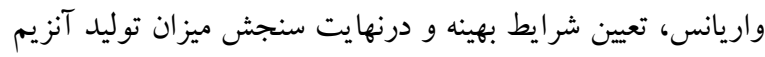

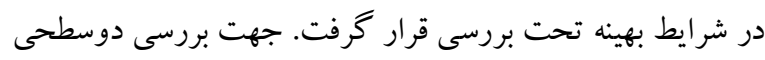

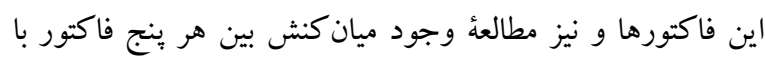

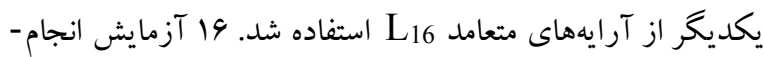

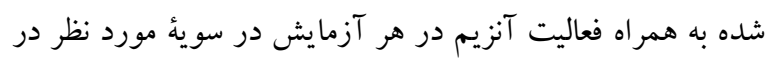

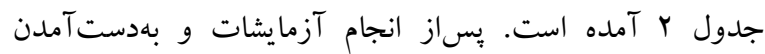




$$
\text { جدول r- Tرايههاى متعامد Lalinivibrio sp. SA2 به براى بهينهسازى فرايند توليد ليياز در تاكوجى. }
$$

Table 2. L L $\mathrm{L}_{16}$ orthogonal array to optimize lipase production in Salinivibrio sp. SA2 using Taguchi method.

\begin{tabular}{|c|c|c|c|c|c|c|}
\hline فعاليت (U/mg) & pH & روغن زيتون & $\left({ }^{\circ} \mathrm{C}\right)$ los & $\begin{array}{c}\text { دور شيكر } \\
\text { (rpm) }\end{array}$ & $\begin{array}{l}\text { نمك } \\
\text { (M) }\end{array}$ & آزمايش \\
\hline $9 \mathrm{~V} / 44$ & v & 1 & ro & $1 .$. & كلريد يتاسيم 1/. & 1 \\
\hline $9 \cdot / 49$ & v & 1 & ro & 10. & كلريد سديم 1 & r \\
\hline $90 / \% 1$ & v & 1 & ro & $1 .$. & كلريد سديم 1 & $r$ \\
\hline $\mathrm{rV} / \Delta \mathrm{A}$ & $\mathrm{v}$ & 1 & ro & 10. & كلريد يتاسيم / /. & f \\
\hline $\mathrm{V} V / \Delta$ & v & r & ro & 1.. & كلريد سديم 1 & $\Delta$ \\
\hline $9 \pi / 1$ & v & r & ro & 10. & كلريد يتاسيم / /. & 4 \\
\hline$\Delta F / 1$ & v & r & ro & $1 .$. & كلريد يتاسيم / /. & v \\
\hline $9 T / 9$ & $\checkmark$ & r & ro & 10. & كلريد سديم 1 & $\wedge$ \\
\hline $\mathrm{Fq} / \mathrm{I}$ & $\wedge$ & 1 & ro & 1.. & كلريد سديم 1 & 9 \\
\hline$\Delta \Delta / V \Delta$ & $\wedge$ & 1 & ro & 10. & كلريد يتاسيم / /. & 1. \\
\hline $1 r \cdot / 4$ & $\wedge$ & 1 & ro & 1.. & كلريد يتاسيم /". & 11 \\
\hline$v \Delta / M$ & $\wedge$ & 1 & ro & 10. & كلريد سديم 1 & ir \\
\hline$\Delta F / \Delta r$ & $\wedge$ & r & ro & 1.. & كلريد يتاسيم / /. & ir \\
\hline $91 / M$ & $\wedge$ & $r$ & ro & 10. & كلريد سديم 1 & if \\
\hline irr & $\wedge$ & r & ro & 1.. & كلريد سديم 1 & 10 \\
\hline$\Delta \cdot / v \Delta$ & $\wedge$ & r & ro & 10. & كلريد يتاسيم //. & 19 \\
\hline
\end{tabular}

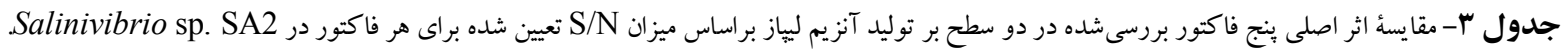

Table 3. Comparison of five factors at two levels affected on lipase production by Salinivibrio sp. SA2, based on the $\mathrm{S} / \mathrm{N}$ for each factor.

\begin{tabular}{|c|c|c|c|}
\hline \multirow[t]{2}{*}{ مقدار بهينه } & \multicolumn{2}{|c|}{ ميزان S/N اصلى } & \multirow[t]{2}{*}{ فاكتور } \\
\hline & سطح r & سطح 1 & \\
\hline$\wedge$ & $W / \Delta F$ & $\Delta Q / \wedge q$ & $\mathrm{pH}$ \\
\hline$r \%$ & VY/Ir & $9 \Delta / Y 9$ & ل روغن زيتون \\
\hline$r \Delta{ }^{\circ} \mathrm{C}$ & $V Y / r I$ & $98 / \cdot 1$ & دما \\
\hline $1 \cdots \mathrm{rpm}$ & $91 / \cdot v$ & $v G / \pi r$ & دور شيكر \\
\hline ا كلريد سديم M & $V \Delta / 9$ & $91 / 1$ & نمك \\
\hline
\end{tabular}


جدول ع- ارزيابى اثر ميان كنش بين جفت فاكتورهاى آزمايش بر توليد آنزيم ليياز در Salinivibrio sp. SA2

Table 4. Evaluation of factor interaction affecting lipase production by Salinivibrio sp. SA2.

\begin{tabular}{|c|c|c|c|c|}
\hline سطح مطلوب فاكتور (opt) & ميانكنش & شدت & $\begin{array}{r}\text { شاخص } \\
\text { (SI) }\end{array}$ & فاكتورها \\
\hline$(r g r)$ & & $\Lambda F / 1$ & & $\operatorname{los}_{0} \times \mathrm{pH}$ \\
\hline$(r, 1)$ & & $v a / 9$ & & دور شيكر × دما \\
\hline$(r g r)$ & & VNI & & روغن زيتون × نوع نمكك \\
\hline$(r g r)$ & & $\Delta \cdot / \Delta \wedge$ & & دور شيكر × نوع نمك \\
\hline$(r, 1)$ & & $r V / \Lambda$ & & دما روغن × زيتون \\
\hline$(r, 1)$ & & $19 / 9$ & & روغن زيتون × دور شيكر \\
\hline$(1, r)$ & & $\mid F / V$ & & نوع نمكك × دما \\
\hline$(r, r)$ & & $9 / r$ & & P × دور شيكر pH \\
\hline$(r, r)$ & & $1 / 9$ & & روغن زيتون × ر ر \\
\hline$(r g r)$ & & /1 & & نوع نمك × pH \\
\hline
\end{tabular}

جدول ه- تحليل واريانس فاكتورها و ميان كنش ميان آنها در توليد آنزيم ليياز در باكترى Salinivibrio sp. SA2

Table 5. ANOVA and interactions of factors in lipid production by Salinivibrio sp. SA2.

\begin{tabular}{|c|c|c|c|c|}
\hline درصد تأثير عامل (٪) & مجموع خالص مربعات ('SS') & مجموع مربعات (SS) & نسبت F & فاكتور \\
\hline $1 r / r 4$ & IYFY/FD & $|Y K T / 9| 1$ & $1.94 / \lambda \mu r$ & $\mathrm{pH}$ \\
\hline$r / \Delta$ & $19 \cdot / r \Lambda$ & $191 / \Delta \Delta$ & $194 / .1$ & روغن زيتون \\
\hline$Y / T V$ & $r I \cdot / \wedge r$ & r11/99 & $|A| / \Delta \mid$ & دما \\
\hline $9 / 94$ & $9 Y \% / 91$ & GYF/VA & $\mathrm{Val/Ar}$ & دور شيكر \\
\hline$N \mid 91$ & $V 91 / 9 V$ & $V G T /$ If & $9 \Delta T / F r$ & نمك \\
\hline • $/$ rma & $r Y / Y I$ & $r / / \mu$ & $r \cdot / \cdot I V$ & pH × روغن زيتون \\
\hline$r M / I I V$ & $1994 / F Y$ & $199 \Delta / \Delta M$ & $19 \wedge \mathrm{N} / \cdot 11$ & $\operatorname{los} \times \mathrm{pH}$ \\
\hline$\cdot / \pi 11$ & rN/AY & $r \cdot / \cdot M \Lambda$ & $r \Delta / v G$ & pH × دور شيكر \\
\hline - & - & $1 / 191$ & - & pH × نوع نمكك \\
\hline $1 / 94$ & $\mid A Y / T \cdot \Delta$ & $\mid \wedge r / r V$ & $10 \mathrm{~V} / .11$ & روغن زيتون × دما \\
\hline $1 / 79$ & $1 r . / .9$ & $|r| / r \pi$ & $1 . r / 1$ & روغن زيتون × دور \\
\hline $10 / F \Delta$ & $\mid f T V / I f$ & $\mid F r N / r \cdot \Lambda$ & IYHI/DHF & روغن زيتون × نوع \\
\hline W/Arr & $|V q \cdot / r|$ & $|V G| / F V A$ & $10 . N K F F$ & دور شيكر × دما \\
\hline ./191 & $\Lambda \cdot / 1$ & N1/Y9N & $99 / \Delta \wedge \Delta$ & نوع نمكك × دما \\
\hline r/AVF & $r 9 \cdot / 4$ & $M 91 / 091$ & $r .9 / \Delta M M I$ & دور شيكر ×نوع \\
\hline
\end{tabular}

(مجموع مربعات با درنظر گرفتن خطا)، F (ميزان اهميت فاكتور بحث

تا اواسط دهؤ .9 ميلادى، كار بئوهشى نسبتاً كمى بر روى نمككدوستها انجام گرفته است. اما امروزه مطالعه درباب اين ميكروار كانيسمها در جنبهاى مختلف فيزيولوزى، اكولوزى، زنتيكك و بيوتكنولوزى توسعه يافته است. ساز گارى و بقاى ميكروار گانيسمهاى نمككدوست نسبى در محيطهاى با كستره:
مورد نظر)، و P (درصد تأثيرفاكتورها) محاسبه شد (جدول ه). فاكتورهاى ميان كنش pH و دما، دما و دور شيكر، غلظت نمكك و روغن، فاكتور pH، دور شيكر و غلظت نمك بهترتيب داراى Salinivibrio sp SA-2 بيشترين اهميت در توليد آنزيم ليياز در 
آمارى و نيز بررسى ميانكنش بين فاكتورها است كه بنابرآن مقدارى متفاوت براى اين فاكتور مشخص شده است.

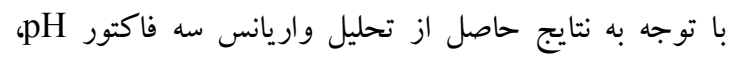
هوادهى و نمكك بيشترين اثر اصلى را در مقايسه با ديكر فاكتورها

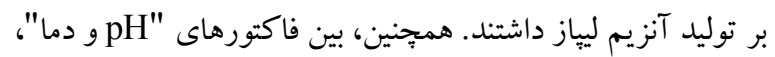

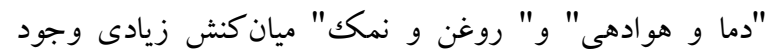

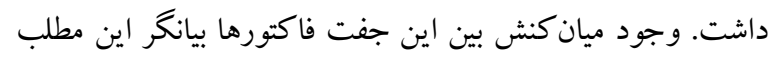

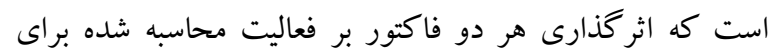

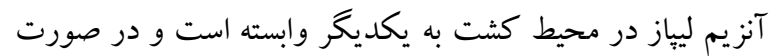

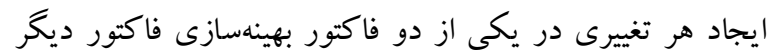

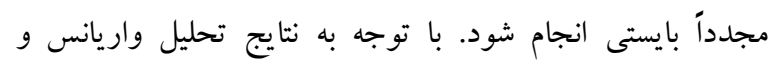

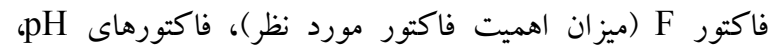

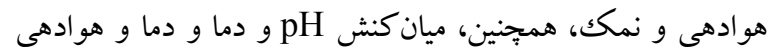

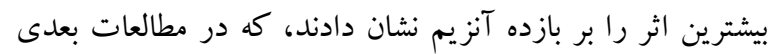

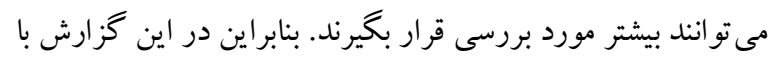

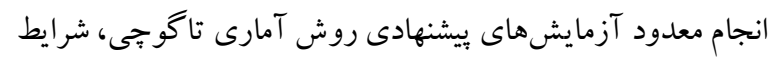

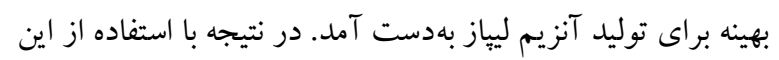

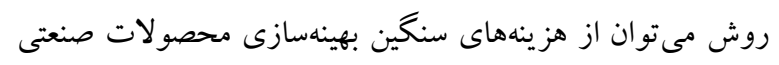

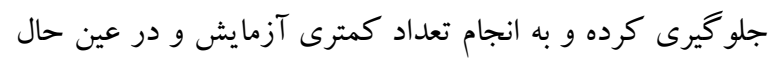
كسب نتايج بهتر دست ييدا نمود.

\section{سياسگزارى}

با سياس از دكتر امير صالحى نجف آبادى كه در طراحى

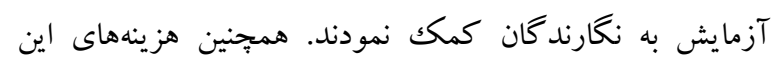

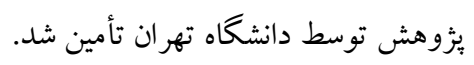

\section{REFERENCES}

Amoozegar, M.A., Salehghamari, E., Khajeh, K., Kabiri, M. and Naddaf, S. 2008. Production of an extracellular thermohalophilic lipase from a moderately halophilic bacterium, Salinivibrio sp. strain SA-2. - J. Basic Microb. 48: 160-167.

Babavalian, H., Amoozegar, M.A., Pourbabaee, A.A., Moghaddam, M.M., and Shakeri, F. 2013. Isolation and identification of moderately halophilic bacteria producing hydrolytic enzymes from the largest hypersaline playa in Iran. - Microbiol. 82: 466-474.

Dalmau, E., Montesinos J.L., Lotti M. and Casas C. 2000. Effect of different carbon sources on lipase production by Candida rugosa. - Enz. Microbiol. Technol. 26: 657663.

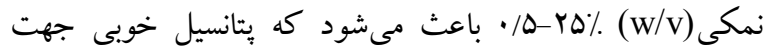

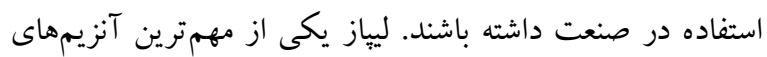

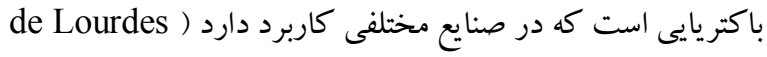
(Moreno et al., 2013

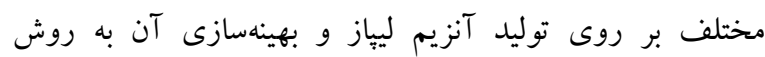

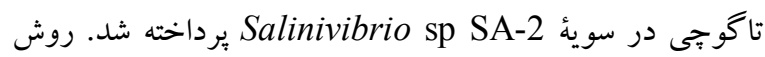

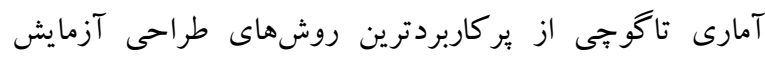

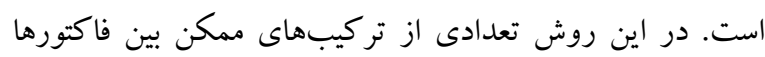

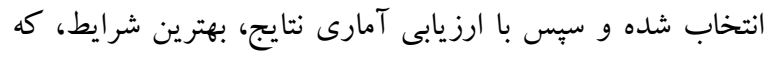

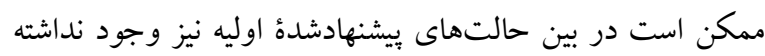

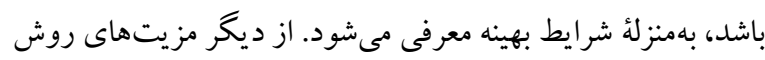

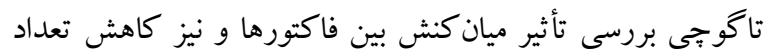

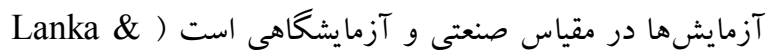

.(Latha 2015

در اين بزّوهش بهينهسازى توليد آنزيم ليياز در باكترى نمك-

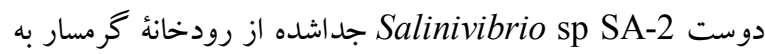

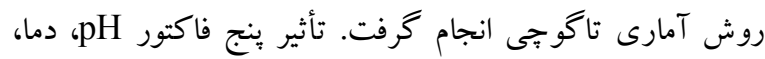
دور شيكر، غلظت روغن زيتون، و نوع نمكك در دو سطح بر توليد

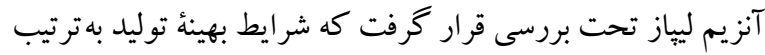
ᄉ،

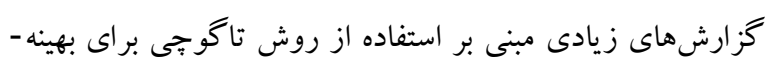

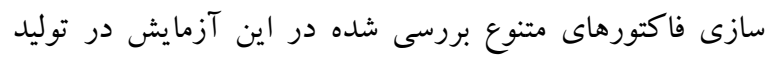

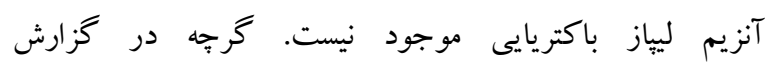
Fabiszewska

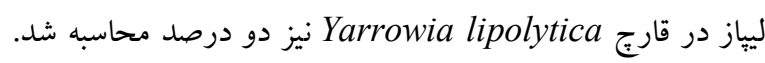
علاوه براين در آزمايشى كه Amoozegar و همكاران (2008)

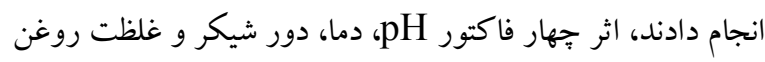

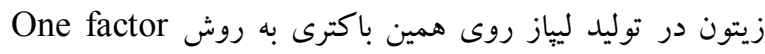

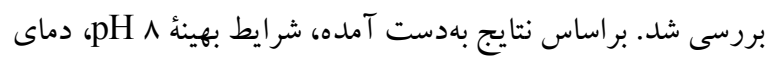

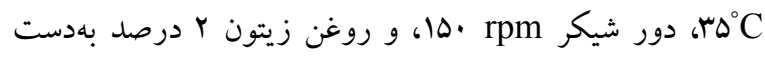

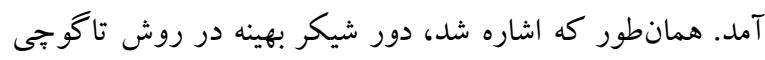

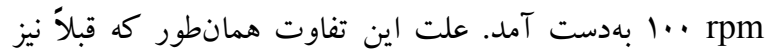
اشاره شد، بررسى همزمان فاكتورها در روش مذكور، محاسبات 
de Lourdes Moreno, M., Pérez, D., García, M. T., and Mellado, E. 2013. Halophilic bacteria as a source of novel hydrolytic enzymes. - Life. 3: 38-51.

Esteban-Torres, M., Mancheño, J.M., de las Rivas, B., and Munoz, R. 2015. Characterization of a halotolerant lipase from the lactic acid bacteria Lactobacillus plantarum useful in food fermentations. - LWT-Food Sci. Techno1. 60: 246-252.

Fabiszewska, A.U., Kotyrba, D., and Nowak, D. 2015. Assortment of carbon sources in medium for Yarrowia lipolytica lipase production: A statistical approach. - Ann. Microb. 65: 1495-1503.

Gupta, R., Beg, Q.K. and Lorenz, P. 2002. Bacterial alkalin proteases: Molecular approaches and industrial applications. - Appl. Microbiol. Biotechnol. 59: 15-32.

Gutiérrez-Arnillas, E., Rodríguez, A., Sanromán, M.A., and Deive, F.J. 2016. New sources of halophilic lipases: isolation of bacteria from Spanish and Turkish saltworks. - Biochem. Eng. J. 109: 170-177.

Jaerger, K.E., Dijkstra, B.W. and Reetz, M.T. 1999 Bacterial biocatalysts: Molecular biology, three dimensional structures and biotechnological applications of lipases. Ann. Rev. Microbiol. 53: 315-351.

Kamekura, M.A and Kushner, D.J. 1984. Effect of chloride and glutamate on in vitro protein synthesis by the moderate halophile Vi-brio costicola. - J. Bacteriol. 160: 385-390.

Kim, S.S, Kim, E.K. and Rhee, J.S. 1996. Effects of growth rate on production of $P$. fluorescens lipase during the fed-batch cultivation of E. coli. - Biotechnol. Prog. 12: 718-722.

Kumar, S., Karan, R., Kapoor, S., Singh, S.P., and Khare, S.K. 2012. Screening and isolation of halophilic bacteria producing industrially important enzymes. - Braz. J. Microb. 43: 1595-1603.

Lanka, S., and Latha, J. 2015. Taguchi design of experiments for the optimization of lipase production by Emericella Nidulans DAOM 222012 isolated from palm oil mill effluent (Pome) dump sites. - Int. J. Appl. Biol. Pharm. Technol. 6: 64-71.

Schreck, S.D., and Grunden, A.M. 2014. Biotechnological applications of halophilic lipases and thioesterases. Appl. Microb. Biotech. 98: 1011-1021.

Surinenite, B., Bendikiene, V. and Juodka, B. 2002. Characterization and physicochemical properties of a lipase from Pseoudomonas mendosina 3121-1. -Biotechnol. Appl. Biochem. 30: 47-55.

Ventosa, A. and Nietoj, J. 1995. Biotechnological applications of halophilic microorganisms. - World J. Microbiol. Biotechnol. 11: 85-94.
Ventosa. A., Nietoj, J. and Oren, A. 1998. Biology of moderately halophilic aerobic bacteria. - Microbiol. Mol. Bio. Rev. 62: 504-544.

$$
* * * * *
$$

Salehghamari, E. and Amoozegar, M.A. 2017. Optimiza tion of lipase production in Salinivibrio sp. SA2 by Taguchi design. - Nova Biol. Rep. 3: 288-294.

$$
\begin{aligned}
& \text { صالحقمرى، ا. و آموز }
\end{aligned}
$$

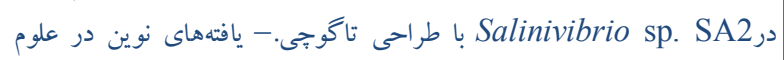

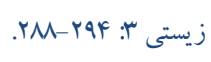

